\title{
Nocardia puris sp. nov.
}

Correspondence

Atteyet F. Yassin

yassin@mibi03.meb.uni-bonn.de

\author{
A. F. Yassin, ${ }^{1}$ B. Sträubler, ${ }^{2}$ P. Schumann ${ }^{2}$ and K. P. Schaal ${ }^{1}$ \\ ${ }^{1}$ Institut für Medizinische Mikrobiologie und Immunologie der Universität Bonn, D-53127 Bonn, \\ Germany \\ ${ }^{2} \mathrm{DSMZ}$ - Deutsche Sammlung von Mikroorganismen und Zellkulturen, Mascheroder Weg 1b, \\ 38124 Braunschweig, Germany
}

The application of chemotaxonomic methods (Collins et al., 1977; Kroppenstedt, 1985; Lechevalier, 1976; Lechevalier et al., 1977; Minnikin et al., 1980; Schleifer \& Kandler, 1972), in combination with a phylogenetic approach based on $16 \mathrm{~S}$ rRNA gene sequence analyses (Chun \& Goodfellow, 1995; Ruimy et al., 1994; Rainey et al., 1995; Stackebrandt \& Goodfellow, 1991; Stackebrandt et al., 1997; Stackebrandt \& Goebel, 1994; Stackebrandt \& Woese, 1981), has resulted in a much improved taxonomy of the genus Nocardia (Goodfellow et al., 1999). The improved classification provides a sound framework for the recognition of additional species and for resolving the taxonomy of isolates which were collectively assigned to the Nocardia asteroides complex. Thus far, Nocardia abscessus (Yassin et al., 2000b) and Nocardia cyriacigeorgica (Yassin et al., 2001) equated to some strains originally classified as Nocardia asteroides subgroup IIIA by Schaal \& Reutersberg (1978). The genus Nocardia, at the time of writing, encompasses 30 validly described species, which form a distinct phylogenetic line within the suborder Corynebacteriniae (Stackebrandt et al., 1997) that constitutes a home for the mycolic-acidcontaining genera of the order Actinomycetales. This study describes a novel Nocardia species isolated from a human abscess. Based on phylogenetic and phenotypic data, it is proposed that this species (strain IMMIB R-145 ${ }^{\mathrm{T}}$ ) be classified as Nocardia puris.

Strain IMMIB R- $145^{\mathrm{T}}$ was cultured on Brain-Heart Infusion (BHI) agar to determine its morphological properties. The

The GenBank accession number for the $16 \mathrm{~S}$ rDNA sequence of Nocardia puris IMMIB R-145 ${ }^{\top}$ is AJ508748. strain was biochemically characterized by using tests to determine hydrolysis of complex substrates as described previously (Gordon, 1966, 1967; Gordon \& Mihm, 1957) as well as tests to determine carbon source utilization according to Yassin et al. (1995). The isomeric form of the diaminopimelic acid was determined by the methods of Becker et al. (1964) and whole-cell sugars were determined by the method of Lechevalier (1968). Lipids were extracted using acid methanolysis and mycolic acids were detected with TLC as described by Minnikin et al. (1980); pyrolysis gas chromatography of the mycolates was performed according to Yassin et al. (1993a). Non-hydroxylated fatty acids were purified, identified and quantified by gas chromatography as described by Yassin (1988). Menaquinones were extracted, purified and identified according to Collins et al. (1977). Phospholipids were extracted, purified and identified as described previously (Yassin et al., 1993c).

DNA was isolated and purified as described previously (Yassin et al., 2000a). DNA-DNA hybridization studies were carried out by using the thermal renaturation method (Yassin et al., 1993b). Genomic DNA extraction, PCRmediated amplification of the $16 \mathrm{~S}$ rDNA and the purification of PCR products were carried out using procedures described previously (Rainey et al., 1996). Purified PCR products were sequenced using a Taq DyeDeoxy Terminator Cycle Sequencing Kit (Applied Biosystems) as described in the manufacturer's protocol. An Applied Biosystems 310 DNA Genetic Analyser was used for the electrophoresis of the sequence reaction products. The $16 \mathrm{~S}$ rDNA sequence of strain IMMIB R- $145^{\mathrm{T}}$ as well as those of the validly described species of the genus Nocardia retrieved from the 
GenBank database were added to the ARB database (Ludwig \& Strunk, 1996) and aligned using the respective tool of the ARB package. The resulting alignment was corrected manually and evolutionary trees were inferred using the maximum-parsimony (Kluge \& Farris, 1969), neighbourjoining (Saitou \& Nei, 1987) and maximum-likelihood (Felsenstein, 1981) algorithms. An evolutionary distance matrix was calculated using the corrections of Jukes \& Cantor (1969). The tree topology was evaluated according to the results of the neighbour-joining and maximumlikelihood analyses. The phylogenetic analyses were carried out using the ARB package (Ludwig \& Strunk, 1996).

Strain IMMIB R-145 ${ }^{\mathrm{T}}$ has morphological properties

Table 1. Differential physiological characteristics of strain IMMIB $R-145^{\top}$ and other significant validly described Nocardia species

Strain: 1, IMMIB R-145 ${ }^{\mathrm{T}} ; 2$, N. veterana DSM $44445^{\mathrm{T}} ; 3, N$. africana SD769 $; 4$, N. ignorata DSM 44496 ${ }^{\mathrm{T}}$; 5, N. salmonicida JCM $4826^{\mathrm{T}}$;

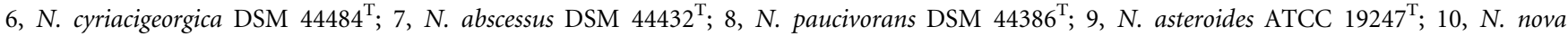
ATCC $33726^{\mathrm{T}}$; 11, N. brasiliensis DSM $43758^{\mathrm{T}} ; 12, N$. farcinica DSM 43665 ${ }^{\mathrm{T}}$; 13 , N. otitidiscaviarum DSM 43242 $; 14, N$. vaccinii DSM $43285^{\mathrm{T}} ; 15$, N. transvalensis NCTC $2392^{\mathrm{T}} ; 16$, N. beijingensis JCM $10666^{\mathrm{T}}$ (data from Wang et al., 2001). -, Negative; +, positive; ND, not determined; w, weakly utilized after 3 weeks incubation; d, different, some strains are positive and some are negative.

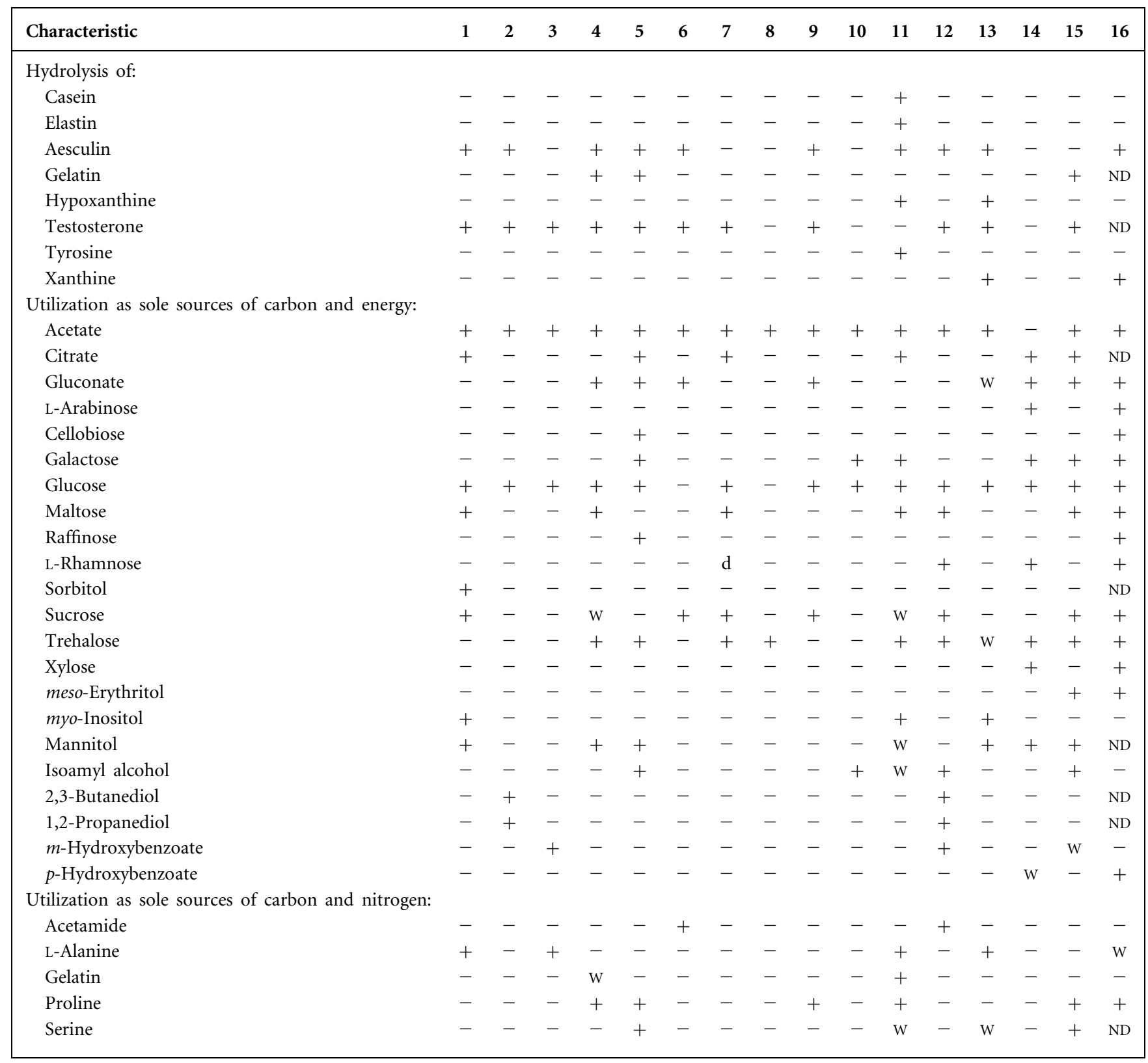


consistent with its assignment to the genus Nocardia. It is an aerobic organism which forms hyphae that are Grampositive and slightly acid-alcohol-fast. The vegetative hyphae were well developed with irregular branches penetrating the agar and bearing white aerial hyphae. At a late stage of growth, the hyphae fragment into rod-shaped elements characteristic of nocardiae. The physiological properties of strain IMMIB R-145 ${ }^{\mathrm{T}}$ are given in the species description (see below). Differences in the biochemical characteristics of strain IMMIB R $-145^{\mathrm{T}}$ compared to those of some of the validly described species of the genus Nocardia examined in this study can be found in Table 1.

Chemotaxonomically, strain IMMIB R-145 ${ }^{\mathrm{T}}$ contained chemical markers which support its assignment to the genus Nocardia. The cell wall contains meso-diaminopimelic acid as well as arabinose and galactose (i.e. wall chemotype IV sensu Lechevalier \& Lechevalier, 1970). One-dimensional TLC of whole-cell acid methanolysates of strain IMMIB $\mathrm{R}-145^{\mathrm{T}}$ revealed the presence of two lipid spots on the chromatogram: the lower one corresponded to mycolic acids as identified by its $R_{\mathrm{F}}$ value $(0 \cdot 47)$ and the higher one corresponded to the non-hydroxylated fatty acids. Pyrolysis gas chromatography of the purified mycolic acid methyl esters from strain IMMIB R- $145^{\mathrm{T}}$ released fatty acid methyl esters of $\mathrm{C}_{14: 0}(4.4 \%$ of total cleavage products $), \mathrm{C}_{16: 0}$ $(61.5 \%), \mathrm{C}_{17: 0}(3.6 \%)$ and $\mathrm{C}_{18: 0}(30.6 \%)$ as pyrolysis cleavage products. Gas chromatographic analyses of the non-hydroxylated fatty acid methyl esters revealed the presence of tetradecanoate $(0.9 \%$ of total fatty acids), pentadecanoate $(0 \cdot 6 \%)$, cis-hexadecenoate $(3 \cdot 1 \%)$, hexadecanoate $(32.7 \%)$, heptadecanoate $(2.40 \%)$, octadecenoate $(10 \cdot 0 \%)$, octadecanoate $(14.0 \%)$, tuberculostearic acid (10-methyl octadecanoate, $20 \cdot 4 \%$ ), nonadecanoate $(0 \cdot 2 \%)$, eicosenoate $(6 \cdot 0 \%)$, eicosanoate $(4 \cdot 7 \%)$, heneicosenoate $(0.4 \%)$, heneicosanoate $(0.3 \%)$, docosenoate $(3 \cdot 0 \%)$ and docosanoate $(2 \cdot 1 \%)$ as the major cellular fatty acid methyl esters. Polar lipid analysis showed that strain IMMIB R $-145^{\mathrm{T}}$ contains phosphatidylethanolamine, phosphatidylinositol, phosphatidylinositol mannoside and diphosphatidylglycerol as the characteristic phospholipids (i.e. phospholipid type PII sensu Lechevalier et al., 1977). Mass spectral analysis of the respiratory quinones showed that strain IMMIB $\mathrm{R}-145^{\mathrm{T}}$ possesses hexahydrogenated menaquinones with eight isoprene units in which the two terminal isoprene moieties are cyclized. The main component corresponds to MK-8 $\left(\mathrm{H}_{6}\right)$ and the minor component corresponds to 2,3-epoxy-MK- $8\left(\mathrm{H}_{6}\right)$. These chemotaxonomic similarities to the validly described species of the genus Nocardia are supported by the high levels of $16 \mathrm{~S}$ rRNA gene sequence similarity observed between isolate IMMIB R-145 $5^{\mathrm{T}}$ and members of the genus Nocardia $(>95 \%)$.

To ascertain the phylogenetic position of strain IMMIB $\mathrm{R}-145^{\mathrm{T}}$, its almost-complete $16 \mathrm{~S}$ rRNA gene sequence [1474 nt; $95.6 \%$ of the Escherichia coli sequence (Brosius et al., 1978)] was determined in this study and subjected to a comparative analysis. The $16 \mathrm{~S}$ rRNA gene sequence comparison clearly showed that strain IMMIB R $-145^{\mathrm{T}}$ is a member of the family Nocardiaceae (Stackebrandt et al., 1997) and that the determined sequence contains all the signature nucleotides designated for this lineage. The high values for the $16 \mathrm{~S}$ rRNA gene sequence similarity to other previously described members of the genus Nocardia $(95 \cdot 5-98 \cdot 3 \%)$ support the addition of strain IMMIB $\mathrm{R}-145^{\mathrm{T}}$ to this genus. Significantly lower levels of similarity were shown with other taxa of the order Actinomycetales (data not shown). Highest sequence similarities were shown with Nocardia abscessus $(97 \cdot 8 \%)$, Nocardia cyriacigeorgica $(97 \cdot 9 \%)$ and Nocardia farcinica (98.3\% sequence similarity). A tree, constructed using the neighbour-joining method, depicting the phylogenetic placement of strain IMMIB R-145 $5^{\mathrm{T}}$ within a subset of the genus Nocardia is shown in Fig. 1. It was evident from the tree that strain IMMIB R- $145^{\mathrm{T}}$ represents a distinct subline within the genus Nocardia that is associated with Nocardia beijingensis, Nocardia brasiliensis, N. farcinica and Nocardia transvalensis;

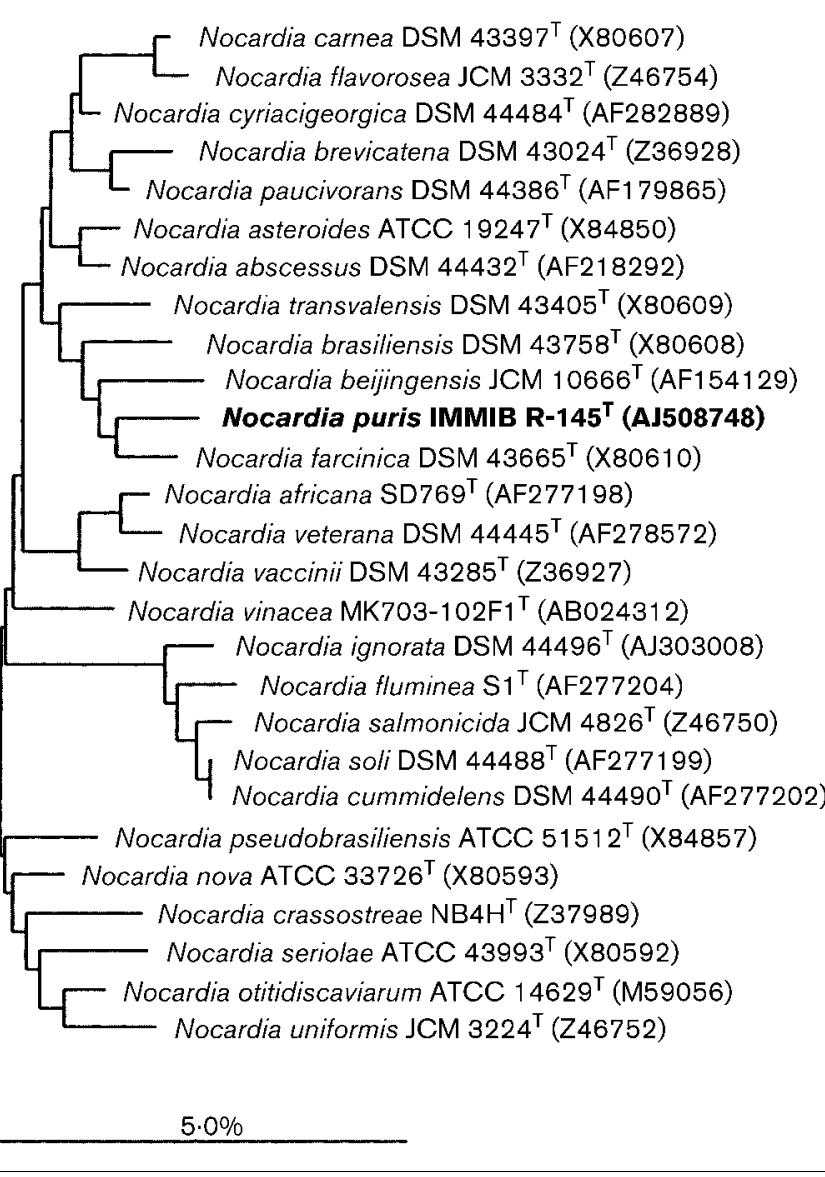

Fig. 1. Unrooted phylogenetic tree showing the position of strain IMMIB R-145 ${ }^{\top}$ within the radiation of species of the genus Nocardia. The tree, constructed using the neighbourjoining method, was based on a comparison of sequences that were at least $90 \%$ complete (with regard to $E$. coli sequence). Bar, $5.0 \%$ sequence divergence. 
the strain displayed sequence similarity values of $97 \cdot 6,97 \cdot 5$, 98.3 and $97.6 \%$, respectively, with these species. These results suggest that strain IMMIB $\mathrm{R}-145^{\mathrm{T}}$ belongs to a genetically distinct Nocardia species. However, the sequence similarity values are too high to allow the definition of a new species on the basis of $16 \mathrm{~S}$ rDNA sequence alone, since values below $97 \%$ sequence similarity and/or genomic DNA reassociation values below $70 \%$ are considered relevant for the establishment of new bacterial species (Stackebrandt \& Goebel, 1994). In view of the high levels of $16 \mathrm{~S}$ rDNA sequence similarity between strain IMMIB R-145 ${ }^{\mathrm{T}}$ and some Nocardia species, chromosomal DNA-DNA hybridization studies were performed to establish whether strain IMMIB R- $145^{\mathrm{T}}$ represents a distinct species of the genus Nocardia. Strain IMMIB R-145 ${ }^{\mathrm{T}}$ displayed low levels of DNA-DNA reassociation with $N$. abscessus DSM $44432^{\mathrm{T}}$ $(20 \cdot 6 \%), N$. cyriacigeorgica DSM $44484^{\mathrm{T}}(37 \cdot 6 \%)$ and N. farcinica DSM $43665^{\mathrm{T}}(42 \cdot 3 \%)$, results which are below the cut-off point recommended for the circumscription of bacterial genomic species by Wayne et al. (1987) and confirm the separation of strain IMMIB R- $145^{\mathrm{T}}$ from its nearest phylogenetic neighbours.

The genus Nocardia contains a number of species for which numerous distinctive characters have been described that fully justify their classification in separate species but that exhibit only limited $16 \mathrm{~S}$ rDNA divergence. For instance, the $16 \mathrm{~S} \mathrm{rDNA}$ of $N$. beijingensis is $97 \cdot 6$ and $97 \cdot 5 \%$ similar to that of $N$. brasiliensis and N. farcinica, respectively, though the distinction between $N$. beijingensis and the two species has been convincingly illustrated by different characters and did not require the determination of DNA hybridization values (Wang et al., 2001). Similarly, Nocardia vaccinii and Nocardia africana share $98 \cdot 5-98 \cdot 7 \% 16 \mathrm{~S}$ rDNA sequence similarity (Hamid et al., 2001). More critical examples are Nocardia veterana and N. africana, the $16 \mathrm{~S}$ rDNA of which are $99 \cdot 3 \%$ similar, whereas the total labelled genomic DNA of the two species exhibits only $28 \cdot 8 \%$ homology. Similar situations were found for Nocardia brevicatena and Nocardia paucivorans, which have a $16 \mathrm{~S}$ rDNA similarity value of $99.6 \%$ but $61.9 \%$ DNA-DNA relatedness (Yassin et al., 2000a), and for Nocardia carnea and Nocardia flavorosea, which have a $16 \mathrm{~S}$ rRNA similarity value of $99 \cdot 2 \%$ but $5.0 \%$ DNA-DNA relatedness (Chun et al., 1998). The $97 \%$ limit is thus not always fulfilled in the genus Nocardia and additional distinctive characteristics must be determined to allow the definition of a new species. Given the $2 \cdot 4-2 \cdot 5 \%$ sequence divergence values of strain IMMIB R $-145^{\mathrm{T}}$ and its closest relatives $N$. transvalensis, $N$. beijingensis and $N$. brasiliensis on the one hand and the biochemical tests presented in Table 1 to discriminate strain IMMIB R $-145^{\mathrm{T}}$ from the last three species on the other hand, we feel that it is reasonable to define a new species of the genus Nocardia. The chemical (and morphological) data clearly indicate that strain IMMIB R $-145^{\mathrm{T}}$ belongs to the genus Nocardia, and the $16 \mathrm{~S}$ rDNA sequencing, DNADNA pairing and biochemical results indicate that it forms a new species when compared with the type strains of validly described species of the genus Nocardia. Thus, on the basis of the results of the reported polyphasic taxonomic study, we consider that strain IMMIB R-145 $5^{\mathrm{T}}$ merits classification as a new species of the genus Nocardia, for which the name Nocardia puris is proposed.

\section{Description of Nocardia puris sp. nov.}

Nocardia puris (pu'ris. L. gen. neut. n. puris of corrupt matter, pus, pertaining to the abscess from which the type strain was isolated).

Hyphae are Gram-positive and partially acid-alcoholfast. Vegetative hyphae are well developed with irregular branches penetrating the agar; they also bear white aerial hyphae. At a late stage of growth, the hyphae fragment into rod-shaped elements. Grows between 22 and $45^{\circ} \mathrm{C}$. Contains the salient chemotaxonomic characteristics of nocardiae. Mycolic acids cleaved on pyrolysis to release fatty acids of $\mathrm{C}_{14: 0}, \mathrm{C}_{16: 0}, \mathrm{C}_{17: 0}$ and $\mathrm{C}_{18: 0}$, with $\mathrm{C}_{16: 0}$ as the major cleavage product. Hydrolyses aesculin, testosterone and urea but not adenine, casein, elastin, gelatin, guanine, hypoxanthine, tyrosine or xanthine. Assimilates acetate, citrate, glucose, myo-inositol, maltose, mannitol, sorbitol and sucrose as carbon sources but not adonitol, adipate, isoamyl alcohol, arabinose, 2,3-butanediol, cellobiose, meso-erythritol, galactose, gluconate, $m$-hydroxybenzoate, $p$-hydroxybenzoate, lactate, lactose, melezitose, 1,2-propanediol, raffinose, rhamnose, trehalose or xylose. Utilizes alanine but not acetamide, arginine, gelatin, ornithine, proline or serine as simultaneous carbon and nitrogen sources.

The type strain is IMMIB R $-145^{\mathrm{T}}\left(=\mathrm{DSM} 44599^{\mathrm{T}}=\mathrm{NRRL}\right.$ $\left.\mathrm{B}-24204^{\mathrm{T}}\right)$. Isolated from a human abscess.

\section{Note added in proof}

Since this work was submitted for publication, two more species of Nocardia have been described, Nocardia cerradoensis (Albuquerque de Barros et al., 2003) and Nocardia caishijiensis (Zhang et al., 2003).

\section{References}

Albuquerque de Barros, E. V. S., Manfio, G. P., Ribeiro Maitan, V., Mendes Bataus, L. A., Kim, S. B., Maldonado, L. A. \& Goodfellow, M. (2003). Nocardia cerradoensis sp. nov., a novel isolate from Cerrado soil in Brazil. Int J Syst Evol Microbiol 53, 29-33.

Becker, B., Lechevalier, M. P., Gordon, R. E. \& Lechevalier, H. A. (1964). Rapid differentiation between Nocardia and Streptomyces by paper chromatography of whole cell hydrolysates. Appl Microbiol 12, 421-423.

Brosius, J., Palmer, M. L., Kennedy, P. J. \& Noller, H. F. (1978). Complete nucleotide sequence of the $16 \mathrm{~S}$ ribosomal RNA gene from Escherichia coli. Proc Natl Acad Sci U S A 75, 4801-4805.

Chun, J. \& Goodfellow, M. (1995). A phylogenetic analysis of the genus Nocardia with 16S rRNA gene sequences. Int $J$ Syst Bacteriol 45, 240-245.

Chun, J., Seong, C.-N., Bae, K. S., Lee, K.-J., Kang, S.-O., Goodfellow, M. \& Hah, Y. C. (1998). Nocardia flavorosea sp. nov. Int J Syst Bacteriol 49, 901-905. 
Collins, M. D., Pirouz, T., Goodfellow, M. \& Minnikin, D. E. (1977). Distribution of menaquinones in actinomycetes and corynebacteria. J Gen Microbiol 100, 221-230.

Felsenstein, J. (1981). Evolutionary trees from DNA sequences: a maximum likelihood approach. J Mol Evol 17, 368-376.

Goodfellow, M., Isik, K. \& Yates, E. (1999). Actinomycete systematics: an unfinished synthesis. Nova Acta Leopold NF80 (312), 47-82.

Gordon, R. E. (1966). Some criteria for the recognition of Nocardia madurae (Vincent) Blanchard. J Gen Microbiol 45, 355-364.

Gordon, R. E. (1967). The taxonomy of soil bacteria. In The Ecology of Soil Bacteria, pp. 293-321. Edited by T. R. G. Gray \& B. Parkinson. Liverpool: University Press.

Gordon, R. E. \& Mihm, J. M. (1957). A comparative study of some strains received as nocardiae. J Bacteriol 73, 15-27.

Hamid, M. E., Maldonado, L., Sharaf Eldin, G. S., Mohamed, M. F., Saeed, N. S. \& Goodfellow, M. (2001). Nocardia africana sp. nov., a new pathogen isolated from patients with pulmonary infections. $J$ Clin Microbiol 39, 625-630.

Jukes, T. H. \& Cantor, C. R. (1969). Evolution of protein molecules. In Mammalian Protein Metabolism, pp. 21-132. Edited by $\mathrm{H}$. N. Munro. New York: Academic Press.

Kluge, A. G. \& Farris, F. S. (1969). Quantitative phyletics and the evolution of anurans. Syst Zool 18, 1-32.

Kroppenstedt, M. (1985). Fatty acids and menaquinone analysis of actinomycetes and related organisms. In Chemical Methods in Bacterial Systematics, pp. 173-189. Edited by M. Goodfellow \& D. E. Minnikin. London: Academic Press.

Lechevalier, M. P. (1968). Identification of aerobic actinomycetes of clinical importance. J Lab Clin Med 71, 934-944.

Lechevalier, M. P. (1976). The taxonomy of the genus Nocardia: some light at the end of the tunnel? In The Biology of the Nocardiae, pp. 1-33. Edited by M. Goodfellow, G. H. Brownell \& J. A. Serrano. London: Academic Press.

Lechevalier, M. P. \& Lechevalier, H. A. (1970). Chemical composition as a criterion in the classification of aerobic actinomycetes. Int J Syst Bacteriol 20, 435-443.

Lechevalier, M. P., de Bievre, C. \& Lechevalier, H. A. (1977) Chemotaxonomy of aerobic actinomycetes: phospholipid composition. Biochem Syst Ecol 5, 249-260.

Ludwig, W. \& Strunk, O. (1996). ARB - a software environment for sequence data (http://www.arb-home.de).

Minnikin, D. E., Hutchinson, I. G., Caldicott, A. B. \& Goodfellow, M. (1980). Thin-layer chromatography of methanolysates of mycolic acid-containing bacteria. J Chromatogr 188, 221-223.

Rainey, F. A., Burghardt, J., Kroppenstedt, R. M., Klatte, S. \& Stackebrandt, E. (1995). Phylogenetic analysis of the genera Rhodococcus and Nocardia and evidence for the evolutionary origin of the genus Nocardia from within the radiation of Rhodococcus species. Microbiology 141, 523-528.

Rainey, F. A., Ward-Rainey, N., Kroppenstedt, R. M. \& Stackebrandt, E. (1996). The genus Nocardiopsis represents a phylogenetically coherent taxon and a distinct actinomycete lineage: proposal of Nocardiopsiaceae fam. nov. Int J Syst Bacteriol 46, 1088-1092.

Ruimy, R., Boiron, P., Boivin, V. \& Christen, R. (1994). A phylogeny of the genus Nocardia deduced from the analysis of small-subunit ribosomal DNA sequences, including transfer of Nocardia amarae to the genus Gordona as Gordona amarae comb. nov. FEMS Microbiol Lett 123, 261-267.

Saitou, N. \& Nei, M. (1987). The neighbor-joining method: a new method for reconstructing phylogenetic trees. Mol Biol Evol 4, 406-425.

Schaal, K. P. \& Reutersberg, H. (1978). Numerical taxonomy of Nocardia asteroides. Zentbl Bakteriol Mikrobiol Hyg Abt 1 Suppl 6, 53-62.

Schleifer, K. H. \& Kandler, O. (1972). Peptidoglycan types of bacterial cell walls and their taxonomic implications. Bacteriol Rev 36, 407-477.

Stackebrandt, E. \& Goebel, B. M. (1994). Taxonomic note: a place for DNA-DNA reassociation and $16 \mathrm{~S}$ rRNA sequence analysis in the present species definition in bacteriology. Int J Syst Bacteriol 44, 846-849.

Stackebrandt, E. \& Goodfellow, M. (1991). Nucleic Acid Techniques in Bacterial Systematics. Chichester: Wiley.

Stackebrandt, E. \& Woese, C. R. (1981). Towards a phylogeny of actinomycetes and related organisms. Curr Microbiol 5, 197-202.

Stackebrandt, E., Rainey, F. A. \& Ward-Rainey, N. L. (1997). Proposal for a new hierarchic classification system, Actinobacteria classis nov. Int J Syst Bacteriol 47, 479-491.

Wang, L., Zhang, Y., Lu, Z., Shi, Y., Liu, Z., Maldonado, L. \& Goodfellow, M. (2001). Nocardia beijingensis sp. nov., a novel isolate from soil. Int J Syst Evol Microbiol 51, 1783-1788.

Wayne, L. G., Brenner, D. J., Colwell, R. R. \& 9 other authors (1987). International Committee on Systematic Bacteriology. Report of the ad hoc committee on reconciliation of approaches to bacterial systematics. Int J Syst Bacteriol 37, 463-464.

Yassin, A. F. (1988). Chemotaxonomic Untersuchungen zur vereinfachten Differenzierung und Identifizierung von aeroben Aktinomyzeten und Mykobakterien. Inaugural-Dissertation zur Erlangung des Doktorgrades der Mathematische-Naturwissenschaftlichen Fakultät der Rheinischen Friedrich-Wilhelms-Universität Bonn.

Yassin, A. F., Binder, C. \& Schaal, K. P. (1993a). Identification of mycobacterial isolates by thin-layer and capillary gas-liquid chromatography under diagnostic routine conditions. Zentbl Bakteriol 278, 34-48.

Yassin, A. F., Galinski, E. A., Wohlfarth, A., Jahnke, K.-D., Schaal, K. P. \& Trüper, H. G. (1993b). A new actinomycete species, Nocardiopsis lucentensis sp. nov. Int J Syst Bacteriol 43, 266-271.

Yassin, A. F., Haggenei, B., Budzikiewicz, H. \& Schaal, K. P. (1993c). Fatty acid and polar lipid composition of the genus Amycolatopsis: application of fast atom bombardment-mass spectrometry to structure analysis of underivatized phospholipids. Int J Syst Bacteriol 43, 414-420.

Yassin, A. F., Rainey, F. A., Brzezinka, H., Burghardt, J., Lee, H. J. \& Schaal, K. P. (1995). Tsukamurella inchonensis sp. nov. Int J Syst Bacteriol 45, 522-527.

Yassin, A. F., Rainey, F. A., Burghardt, J., Brzezinka, H., Mauch, M. \& Schaal, K. P. (2000a). Nocardia paucivorans sp. nov. Int J Syst Evol Microbiol 50, 803-809.

Yassin, A. F., Rainey, F. A., Mendrock, U., Brzezinka, H. \& Schaal, K. P. (2000b). Nocardia abscessus sp. nov. Int J Syst Evol Microbiol 50, 1487-1493.

Yassin, A. F., Rainey, F. A. \& Steiner, U. (2001). Nocardia cyriacigeorgici sp. nov. Int J Syst Evol Microbiol 51, 1419-1423.

Zhang, J., Liu, Z. \& Goodfellow, M. (2003). Nocardia caishijiensis sp. nov., a novel soil actinomycete. Int J Syst Evol Microbiol 53, 999-1004. 